\title{
Determinants of Online Banking Adoption among Ghanaian University Students
}

\author{
Benjamin B. Angenu, Fedelis Quansah, Abednego F. Okoe* \\ Faculty of Management Studies, University of Professional Studies, Accra, Ghana \\ Email: ${ }^{*}$ okoe67@yahoo.com
}

Received 23 December 2014; accepted 30 March 2015; published 1 April 2015

Copyright (C) 2015 by authors and Scientific Research Publishing Inc.

This work is licensed under the Creative Commons Attribution International License (CC BY). http://creativecommons.org/licenses/by/4.0/

cC) (i) Open Access

\begin{abstract}
The objective of this study is to determine bank customers' awareness of Internet banking and the effect of trust and customer loyalty on Internet banking adoption intentions. The study employed the survey research design. The population of the study consisted of university students in Ghana. The convenience sampling technique was used to select the respondents. Data were analysed using multiple regression. The findings indicate that the respondents are aware of Internet banking. Additionally, the study found awareness, trust and customer loyalty as antecedents of Internet banking adoption. Recommendations have been provided at the end of the study.
\end{abstract}

\section{Keywords}

Ghana, Internet Banking, Internet Adoption, Customer Loyalty

\section{Introduction}

Some decades ago, almost all service encounters were in the form of personal meetings between a service provider and a customer. Today banking on the Internet, with no or limited interpersonal contact between the service provider and the customer, has for many people become the most important way to interact with their banks. Internet banking has become a very common service that is provided by most of the commercial banks in Ghana. Internet services adopted by banks in this dynamic era give banks a superior edge over its competitors and satisfy customers better [1]. Internet banking allows customers of financial institutions to conduct financial transactions on a secured website operated by the institution, which can be a retail, virtual bank or credit union [2]. Internet banking offers an "Internet portal”, through which customers can use different kinds of banking services ranging from bill payment to making investments with the exception of cash withdrawals [3].

In spite of the numerous benefits that Internet banking offers customers, Internet banking penetration and

\footnotetext{
${ }^{*}$ Corresponding author.
}

How to cite this paper: Angenu, B.B., Quansah, F. and Okoe, A.F. (2015) Determinants of Online Banking Adoption among Ghanaian University Students. Journal of Service Science and Management, 8, 183-190. 
awareness among bank customers in Ghana appear to be low [4]. Again, like most information system studies, researches on Internet banking adoption have employed the technology acceptance model [5]. However, in terms of explaining security factors that can affect users' general acceptance for information system like Internet banking, the model is limited. The extant literature has identified customer loyalty as a critical factor in consumer behavioural patterns. However, little is known about the role of customer loyalty in Internet banking adoption. The objective of this study, therefore, is to find bank customers' awareness of Internet banking the effect of trust and customer loyalty in Internet banking adoption intention. The rest of the paper is divided as follows: Section 2 focuses on literature review while Section 3 presents the methodology employed; Section 4 presents the findings of the study while the Section 5 focuses on the discussions and conclusions.

\section{Literature Review}

\subsection{Internet and Internet Banking}

Internet banking is the situation where customers can access their bank account via the Internet using a PC or mobile phone and web-browser [6]. It is a means through which customers of the bank have access to their account always at any time and any place that the service is available through the Internet. The Internet can also be referred to as "a type of global information infrastructure consisting of computer hardware and software that is characterized as both general and open" [7]. In this case, general means that Internet was not designed for a specific set of services. Since all specifications required using the Internet is publicly available, it can also be described as "open". Further on, "the Internet" will refer both to the Internet "itself" and to information and communication technologies (i.e. the systems behind the Internet technology).

Internet banking is developed to help banks deliver services and products better, faster, and cheaper. It enables customers to browse essential bank products and services seven days a week through their personal computers [8]. It allows consumers to perform banking transactions over the Internet anywhere and anytime. Internet banking enables customers to transfer funds, download and print statements, request for cheque book and savings withdrawal booklet, establish and modify standing orders and make payments through the Internet among others.

The Reserve Bank of India classified Internet banking services into three basic types. They are; the informational, communicative and transactional Internet banking services. Informational Internet banking is a basic type of Internet banking that provides comprehensive bank products and services information [9]. It provides background and history of the bank, organizational structure, affiliated entities in the banking group and available corporate, retail and specialized banking facilities [10]. This type of Internet banking does not involve any execution of transactions [10]. The bank provides Internet users with basic information through hyperlinks. Communicative Internet banking is the second type of Internet banking that allows customers to have some interactions with bank system such as to submit their applications and queries for different Internet banking services, but it does not allow money transactions between accounts. Similar to informational Internet banking, it does not involve execution of transactions. Since the web server of communicative Internet banking is linked with the internal network of a bank, it is at a higher security risk compared to informational Internet banking services.

Transactional Internet banking is the third type of Internet banking that allows the customers to transfer funds, make payments, and update personal information [11]. The server and the internal network of the bank's outsourcers pose the highest security risk and deserve the strongest controls [11]. Security and safety, confidentiality and privacy issues of the customers' accounts are critical. The accuracy and integrity of transaction records need to be ensured at all time.

From the banks point of view, [12] postulates that Internet offers opportunities to create service processes that demand few internal resources, and therefore lower the costs. Since Internet has no restrictions in location or hours of operations it also provides wider availability and a possibility to reach more customers. Real-time adjustments to a bank's offerings are possible, since the information presented on the Internet site can be updated at any time. On the Internet however, the bank cannot differentiate the character of the branch from those of competitors. Instead it will be important to differentiate the service, concentrating on things like security, design and user friendliness of the Internet bank as well as creation of sustainable personal relationships with their customers. The absence of face-to face contact might give customers a feeling of uncertainty and risk [13] and a lot of reassurance might be needed before they will hand over personal details and preferences. Ref. [14] reported that although Internet banking reduces the distance between customers and banks, the technology does not help 
those customers who prefer face-to-face communication, especially for older people who may be reluctant to use the Internet. Nevertheless, it is important for the bank to show that it deserves the customers trust [15], by using secure transaction software, provide clear explanations of the level of security and deliver one's promises. A reduction in the percentage of customers visiting banks with an increase in alternative channels of distribution will also minimize the queues in the branches [16]. Increased availability and accessibility of more self-service distribution channels help bank administration in reducing the expensive branch network and its associate staff overheads. Bank employees and office space that are released in this way may be used for some other profitable ventures [17]. This ultimately leads towards improved customer satisfaction and the institution's bottom line [16].

Customers generally enjoy accessibility and convenience with Internet banking services. For the customer Internet enhances the possibility to take more part in the process of service production and consumption and to affect the performance of the financial service [18].

This is because the customer himself/herself to a great extent carries out services on the Internet, instead of the branch personnel [12]. Since Internet is not constrained by either location or time [7], it is possible to make use of a service provided on the Internet from off-site locations at any time, therefore, the customer does not need to travel to the bank to consume a service. Another feature of the Internet is that it increases the transparency because it offers the customer a possibility of getting a total view of banks available in the market. It enables the customer to obtain information on various competing services, which makes it possible to compare them and then select the one that best meets his or her requirements [19]. Therefore, creating loyalty among customers might be even more important in online banking than in conventional banking.

\subsection{Factors Influencing Internet Adoption}

Ref. [20] identified four characteristics (Ease of use, usefulness, cost saved and self-control) that determine the customer acceptance of e-banking services. These are as follows:

\subsubsection{Accessibility}

Accessibility is defined as the ability and the ease of users to access information and services from the web or device providing the service. This is dependent on many factors. These include the content format; the user's hardware, software and settings; Internet connections; the environmental conditions and the user's abilities and disabilities [21]. The techniques and approaches that create more accessible web pages for people also address many other access issues such as download speed and discoverability. Ref. [21] revealed that reliable/ prompt responses, attentiveness, and ease of use had considerable impacts on both customers perceived overall service quality and satisfaction. It also indicated that there is a significant positive relationship between overall service quality and satisfaction.

\subsubsection{Customer Loyalty}

Ref. [22] defines customer loyalty as a deeply held commitment to re-buy or re-patronize a preferred product/ service consistently in the future, thereby causing repetitive same-brand or same brand-set purchasing, despite situational influences and marketing efforts having the potential to cause switching behavior. Ref. [23] also defined customer loyalty as the deep commitment to a product, service, brand or organization. Ref. [23] notes that loyal customers show constraint-based loyalty, which means that, they are passive and afraid of changing banks because it could be difficult or they do not see any good alternatives.

\subsubsection{Trust}

In business studies, trust has been found to be important for building and maintaining long-term relationships. Electronic exchanges are believed to present numerous risks to customers while trust appears to be especially important for creating loyalty when the perceived level of risk is high [24]. As a result Ref. [25] noted that trust has been identified as key to customer loyalty especially in the area of e-commerce, because it is crucial wherever risk, uncertainty and interdependence exist. The banking sector is strongly associated with high levels of trust related to security and privacy issues in the physical environment. Ref. [25] stated that trust is an important consideration in the development and fostering of e-commerce relations in the context of knowledge-based economy. Lowering perceived risks associated with online transactions as well as maintaining transaction trust is vital keys to attracting and retaining customers. 


\section{Methodology}

This study employed the survey research design. This was to enable the researchers employ statistical technique to analyse the data and general the findings. The population of the study consists of University students in Ghana. The students were selected from the University of Ghana (UG), Central University College (CUC) and University of Professional Studies, Accra (UPSA). This population was chosen because the students were willing to participate in the study. The convenience sampling technique was used to select the respondents; this decision was based on accessibility and availability of the students. The sample size for the study was 300 and this number is appropriate for multiple regression. Questionnaire was the main instruments for data collection. The questionnaire was developed based on the existing literature. The items were measured on a likert scale of 1 (strongly disagree) to 5 (strongly agree). Data were analysed using multiple regression. This was to enable the researchers test the relationship between the independent variables (accessibility trust and loyalty) and the dependent variable (Internet banking adoption).

\section{Presentation of Findings}

\subsection{Demographics Profile of Respondents}

The respondents' gender as displayed in Table 1 clearly indicates that $54 \%$ of the total respondents who constituted a slight majority were males whilst the remaining $46 \%$ were females. This indicates that there was a good representation of both genders in the sample.

The study also ascertained the ages of the respondents. The results in Table 2 shows that about $80.3 \%$ of respondents were in the age category of 18 - 30 years, followed by about $13.3 \%$ in the age bracket of 31 - 40 years, $4.7 \%$ in the 41 - 50 age category, and finally, 1.7\% of respondents being between 51 - 60 years. Collectively, the table shows that all the respondents were in the economically active population, which suggests that most of them are engaged in some form of income generating activities and hence have appreciable knowledge about the questions being asked in relation to the purpose of this study.

Table 3 highlights the occupational and income distribution of the respondents. The occupational distribution of the respondents had $6.3 \%$ being public sector workers, $10.0 \%$ being private sector workers, $8.7 \%$ being selfemployed whilst 3.0\% are unemployed, 72\% forming the majority were full time students. The income distribution also showed that about $28.2 \%$ of respondent earned an income above GHC 500, whilst $49.6 \%$ earned incomes below GHC 500. The remaining 22.1\% earned no income.

\begin{tabular}{cccc} 
Table 1. Gender equity of respondents. & & \\
\hline Profile & Category & Frequency & Percent \\
\hline \multirow{2}{*}{ Gender } & Male & 162 & $54 \%$ \\
& Female & 138 & $46 \%$ \\
& Total & $\mathbf{3 0 0}$ & $\mathbf{1 0 0 \%}$ \\
\hline
\end{tabular}

Source: Fieldwork, 2014.

Table 2. Age distribution of respondents.

\begin{tabular}{|c|c|c|c|}
\hline Profile & Category & Frequency & Percent \\
\hline \multirow{5}{*}{ Age } & $18-30$ & 241 & $80.3 \%$ \\
\hline & $31-40$ & 40 & $13.3 \%$ \\
\hline & $41-50$ & 14 & $4.7 \%$ \\
\hline & $51-60$ & 5 & $1.7 \%$ \\
\hline & Total & 300 & $100.0 \%$ \\
\hline
\end{tabular}

Source: Fieldwork, 2014. 
Table 3. Occupational and income equity of respondents.

\begin{tabular}{cccc}
\hline Profile & Category & Frequency & Percent \\
\hline \multirow{3}{*}{ Occupation } & Public sector & 19 & $6.3 \%$ \\
& Private sector & 30 & $10 \%$ \\
& Self employed & 26 & $8.7 \%$ \\
& Unemployed & 9 & $3.0 \%$ \\
& Full time student & 216 & $72 \%$ \\
\hline Profile & Total & $\mathbf{3 0 0}$ & $\mathbf{1 0 0 . 0 \%}$ \\
\hline \multirow{3}{*}{ Income } & Category & Frequency & Percent \\
& Below GHC100 & 43 & $14.8 \%$ \\
& GHC100-499 & 101 & $34.8 \%$ \\
& GHC500-999 & 63 & $21.7 \%$ \\
& GHC1000-1999 & 10 & $3.4 \%$ \\
& NH/A & 9 & $3.1 \%$ \\
& Tot more & 64 & $22.1 \%$ \\
\hline
\end{tabular}

Source: Fieldwork, 2014

\subsection{Respondents' Level of Awareness of Internet Banking Services}

The respondents were asked whether they were familiar with Internet services provided by their banks. From the table above, it is seen that 247 of the respondents which represents $82.3 \%$ of the sample were familiar with the Internet services that their banks while 53 respondents representing $17.7 \%$ were not aware (see Table 4). This result shows that most of the students were aware of the Internet services their banks provided.

Furthermore, the research asked if the students were aware of the fact that they could make bank balance enquiry via the bank's Internet banking services. From the Table 5, it is seen that 253 of the respondents which represents $84.3 \%$ of the sample were aware that they could make bank balance enquiry via their bank's Internet banking service while 47 respondents representing $15.7 \%$ were not aware. This result shows that most of the students were aware of the Internet services their banks provided and how they could make use of it.

With reference to the question asked concerning their knowledge of fund transfer via Internet banking services, $97.6 \%$ which is 235 of our 300 respondents were aware of this service while the remaining 7 were not aware (see Table 6).

When asked about student awareness of payment through Internet banking services, 290 of the respondents (96.7\%) responded positively while 10 (3.3\%) had a negative response to this question. This is shown in Table 6 above, where the responses are shown in frequency and percentages (see Table 7).

\subsection{The Regression Model}

Analysis of variance (ANOVA) was performed to determine the suitability of the proposed model. The outcome shows the proposed model was suitable in explaining the relationship $(F=75.286, P=0.000)$. The adjusted $\mathrm{R}^{2}$ was 0.127 indicating that the model correctly explains Internet banking adoption by $12.7 \%$.

From Table 8, the regression model can be written as; Internet banking adoption $=0.256+0.617$ accessibility +0.379 trust +0.260 loyalty. Further analysis shows that, when all other variables are held constant, a change in the accessibility will cause patronage to change by 0.292 . Similarly, when all other variables are held constant, a change in the trust will cause patronage to change by 0.382 also in the same direction. And lastly, when all other variables are held constant, a change in the loyalty level will cause patronage to change by 0.172 in the same direction. The contributions of all the independent variables are statistically significant in the determining of the patronage of Internet banking service. The $P$-value which is 0.00 is less than our significant level of 0.05 and hence making each independent variable important in the model. 
Table 4. Familiarity with the Internet services provided by the bank.

\begin{tabular}{ccc}
\hline Category & Frequency & Percent \\
\hline Yes & 247 & $82.3 \%$ \\
No & 53 & $17.7 \%$ \\
Total & $\mathbf{3 0 0}$ & $\mathbf{1 0 0 . 0} \%$ \\
\hline
\end{tabular}

Source: Fieldwork, 2014.

Table 5. I am aware I can make bank balance enquiry via my bank’s Internet banking service.

\begin{tabular}{ccc}
\hline Category & Frequency & Percent \\
\hline Yes & 253 & $84.3 \%$ \\
No & 47 & $15.7 \%$ \\
Total & $\mathbf{3 0 0}$ & $\mathbf{1 0 0 . 0} \%$ \\
\hline
\end{tabular}

Source: Fieldwork, 2014.

Table 6. I know I can transfer funds via the bank’s Internet banking service.

\begin{tabular}{ccc}
\hline Category & Frequency & Percent \\
\hline Yes & 293 & $97.6 \%$ \\
No & 7 & $2.4 \%$ \\
Total & $\mathbf{3 0 0}$ & $\mathbf{1 0 0 . 0 \%}$ \\
\hline
\end{tabular}

Source: Fieldwork, 2014.

Table 7. I am aware I can make payment using my bank’s Internet banking service.

\begin{tabular}{ccc}
\hline Category & Frequency & Percent \\
\hline Yes & 290 & $96.7 \%$ \\
No & 10 & $3.3 \%$ \\
Total & $\mathbf{3 0 0}$ & $\mathbf{1 0 0 . 0 \%}$ \\
\hline
\end{tabular}

Source: Fieldwork, 2014.

Table 8. Coefficients.

\begin{tabular}{|c|c|c|c|c|c|}
\hline \multirow{2}{*}{ Model } & \multicolumn{2}{|c|}{ Unstandardized coefficients } & \multirow{2}{*}{$\begin{array}{c}\text { Standardized coefficients } \\
\text { Beta }\end{array}$} & \multirow{2}{*}{$\mathrm{T}$} & \multirow{2}{*}{ Sig. } \\
\hline & B & Std. error & & & \\
\hline (Constant) & 0.256 & 0.139 & & 1.834 & 0.068 \\
\hline Accessibility & 0.617 & 0.105 & 0.292 & 5.859 & 0.000 \\
\hline Trust & 0.379 & 0.049 & 0.382 & 7.738 & 0.000 \\
\hline Loyalty & 0.260 & 0.069 & 0.178 & 3.773 & 0.000 \\
\hline
\end{tabular}

Source: Fieldwork, 2014.

\section{Discussion of Results}

Bank technological services, such as checking account balance on phone, availability of ATM's and database management systems, are aimed ultimately at giving greater value to the customer [26]. Ref. [27] stated that students considered the use of electronic banking among others as very important reasons for maintaining an account with their banks. In this case, our study is consistent with their findings. The study found that students were aware of Internet banking services and mostly used it in banking transactions.

The first specific objective of the study was to determine the level of awareness of Internet banking among 
bank customers. The study found that majority of respondents had a good level of awareness of Internet banking services of their banks. This can be explained by the fact that $89.3 \%$ and $85.3 \%$ of the respondents subscribe and use Internet banking services, respectively. Also $82.3 \%$ of the total 300 respondents said that they were familiar with the Internet services provided by their banks; $97.6 \%$ of the respondents affirmed they could make bank balance enquiry via their bank's Internet banking services. From the results, it can be concluded that the respondents are generally aware of the Internet banking services that are provided by their banks.

The study also examined the relationship between Internet banking patronage and accessibility, trust and customer loyalty among bank customers in Ghana. In order to get solid basis on establishing a relationship, between the variables of interest, Bivariate Correlation analysis was performed. The "Pearson’s R" represents the correlation coefficient between the variables tested and the "Sig. value" gives an indication on whether the relationship "linkage" established between the variables is significant or not. The results indicate that there is a positive relationship between student patronage of Internet banking services and loyalty to their banks. This also means that a student's loyalty could be determined by knowing their patronage of the Internet banking service. Customers with high patronage of Internet banking service show that they have a high level of loyalty to their bank and vice versa. This outcome confirms Ref. [28] which reveals that e-banking services have a positive effect on customer loyalty. Ref. [20] also observed that the increased use of Internet banking did affect loyalty, even though it was difficult to draw any specific conclusions from this survey about how it affected loyalty. In another related study which confirmed the current outcome, Ref. [23] gathered evidence from German consumers which suggested that online bank customers were more loyal. They have a higher probability to consider their main bank for the purchase of an additional financial service. The results also show that trust and accessibility are key in Internet banking adoption. Therefore, the banks need to ensure that their Internet banking services are available and accessible to their target audience. Again, the Internet banking system must be secured; this will reduce the perceived risk associated with Internet banking which will result in increase in patronage of Internet banking services.

\section{References}

[1] Joseph, M. and Joseph, B. (1999) Service Quality in Education: A Student Perspective. Quality Assurance in Education, 5, 15-21. http://dx.doi.org/10.1108/09684889710156549

[2] Wolfinbarger, M. and Gilly, M.G. (2003) ETailQ: Dimensionalizing, Measuring and Predicting Tail Quality. Journal of Retailing, 79, 183-198. http://dx.doi.org/10.1016/S0022-4359(03)00034-4

[3] Pikkarainen, T., Pikkarainen, K., Karjaluoto, H. and Pahnila, S. (2004) Consumer Acceptance of Online Banking: An Extension of the Technology Acceptance Model. Internet Research, 14, 57-63. http://dx.doi.org/10.1108/10662240410542652

[4] Nimako, G.S., Kwame Gyamfi, N., Wandaogou, M. and Mumuni, A. (2013) Customer Satisfaction with Internet Banking Service Quality in the Ghanaian Banking Industry. International Journal of Scientific \& Technology Research, 2, 52-68.

[5] Liao, Z. and Cheung, M.T. (2008) Measuring Consumer Satisfaction in Internet Banking: A Core Framework. Communications of the ACM, 51, 47-51. http://dx.doi.org/10.1145/1330311.1330322

[6] Zeithaml, V.A., Parasuraman, A. and Malhotra, A. (2002) An Empirical Examination of the Service Quality-ValueLoyalty Chain in an Electronic Channel. Working Paper, University of North Carolina, Chapel Hill.

[7] Peterson, R.A., Balasubramanian, S. and Bronnenberg, B.J. (1997) Exploring the Implications of the Internet for Consumer Marketing. Journal of the Academy of Marketing Science, 25, 329-346. http://dx.doi.org/10.1177/0092070397254005

[8] Polatoglu, V.N. and Ekin, S. (2001) An Empirical Investigation of the Turkish Consumers' Acceptance of Internet Banking Services. International Journal of Bank Marketing, 19, 156-165. http://dx.doi.org/10.1108/02652320110392527

[9] Momeni, M., Kheiry, B. and Dashtipour, M. (2013) Analysis the Effects of Electronic Banking on Customer Satisfaction and Loyalty (Case Study: Selected Branches of Melli Bank in Tehran). Interdisciplinary Journal of Contemporary Research in Business, 4, 65-73.

[10] Reserve Bank of India (2003) Report on Trend and Progress of Banking in India 2002-2003. Reserve Bank of India, Mumbai.

[11] Puni, A. and Okoe, A. (2013) An Assessment of the Dialogic Potential of Bank Websites as a Strategic Tool. Journal of Business Research, 7, 60-59. 
[12] Grönroos, C., Heinonen, F., Isoniemi, K. and Lindholm, M. (2000) The NetOffer Model: A Case Example from the Virtual Marketspace. Management Decision, 38, 243-252. http://dx.doi.org/10.1108/00251740010326252

[13] Reichheld, F.F. and Schefter, P. (2000) E-Loyalty: Your Secret Weapon on the Web. Harvard Business Review, 78, 105-113.

[14] Clemes, M.D., Gan, C. and Zhang, D. (2010) Customer Switching Behavior in the Chinese Retail Banking Industry. International Journal of Bank Marketing, 28, 519-546. http://dx.doi.org/10.1108/02652321011085185

[15] Cappelli, P. and Clancy, J. (1999) Is Loyalty Really Dead? Across the Board, 36, 14-19.

[16] Thornton, J. and White, L. (2001) Customer Orientations and Usage of Financial Distribution Channels. Journal of Services Marketing, 15, 168-185. http://dx.doi.org/10.1108/08876040110392461

[17] Birch, D. and Young, M.A. (1997) Financial Services and the Internet—What Does Cyberspace Mean for the Financial Services Industry? Internet Research, 7, 120-128. http://dx.doi.org/10.1108/10662249710165262

[18] Rust, R.T. and Lemon, K.N. (2001) E-Service and the Consumer. International Journal of Electronic Commerce, 5, 85-101.

[19] Jansson, E. and Letmark, M. (2005) Customer Loyalty in an Internet Banking Context. Unpublished Dissertation, Submitted to Södertörns högskola University College.

[20] Ho, S.H. and Ko, Y.Y. (2008) Effects of Self-Service Technology on Customer Value and Customer Readiness: The Case of Internet Banking. Internet Research, 18, 427-446. http://dx.doi.org/10.1108/10662240810897826

[21] Hackett, S. and Parmanto, B. (2005) A Longitudinal Evaluation of Accessibility: Higher Education Website. Internet Research, 15, 281-294. http://dx.doi.org/10.1108/10662240510602690

[22] Oliver, S. (1997) A Model for the Future of Electronic Commerce. Information Management \& Computer Security, 5, 166-169. http://dx.doi.org/10.1108/09685229710187221

[23] Lam, S.Y., Shankar, V., Erramilli, M.K. and Murthy, B. (2004) Customer Value, Satisfaction, Loyalty, and Switching Costs: An Illustration from a Business-to-Business Service Context. Journal of the Academy of Marketing Science, 32, 293-311. http://dx.doi.org/10.1177/0092070304263330

[24] Nordman, C. (2004) Understanding Customer Loyalty and Disloyalty - The Effect of Loyalty-Supporting and -Repressing Factors. Svenska handelshögskolan, Swedish School of Economics and Business Administration, Helsinki.

[25] Bryant, A. and Colledge, B. (2002) Trust in Electronic Commerce Business Relationships. Journal of Electronic Commerce Research, 3, 32-39.

[26] Mahmoud, M.A., Tweneboah-Koduah, E.Y. and Danku, C.E. (2011) Key Motivations for Bank Loyalty among University Students in Ghana. Journal of Marketing Development and Competitiveness, 5, 96-107.

[27] Pierson, J., Jacobs, A., Dreesse, K., Van den Broeck, I., Lievens, B. and Van den Broeck, W. (2006) Walking the Interface: Uncovering Practices through 'Proxy Technology Assessment'. Proceedings of the EPIC 2006 Conference, Portland, 24-26 September 2006, 29-40.

[28] Hamid, M.R.A., Amin, H., Lada, S. and Ahmad, N. (2007) A Comparative Analysis of Internet Banking in Malaysia and Thailand. Journal of Internet Business, 4, 1-19. 